\title{
Financial Behavior of the Japanese Firms: Before and After the US Lehman Shock
}

\author{
Chikashi Tsuji \\ Professor, Faculty of Economics \\ Chuo University, Tokyo, Japan
}

\begin{abstract}
This paper studies the financial behavior of the Japanese firms by focusing on, in particular, its difference before and after the US Lehman shock. Findings derived from our analyses are summarized as follows. First, (1) regarding the financial condition in Japan, after the US Lehman shock, the current ratio, the debt ratio, the capital adequacy ratio of the Japanese firms clearly improved. In addition, (2) the fixed assets ratio of the Japanese firms also clearly decreased after the Lehman shock. Further, (3) as to the state of investments, after the Lehman shock, the equity investments of the Japanese firms increased whilst the investments in bonds and real estates as well as the capital investments of the Japanese firms decreased.
\end{abstract}

Keywords: Financial behavior; financial ratio; Japanese firms; Lehman shock

\section{INTRODUCTION}

Financial ratios computed by using firms' accounting variables are important standard measures to understand the financial state of companies. How did the financial state of firms change after financial crises? Introducing the recent interesting studies using financial ratios, Ang and Smedema (2011) analyzed the firms in the US and they found that, on an aggregate basis, the US firms did not appear to prepare for future recessions. In addition, analyzing the US firms, Chen and Chen (2012) found that investment-cash flow sensitivity had decreased over their full sample period and it had completely disappeared in recent years, even during the credit crunch from 2007 to 2009. Further, Tsuji (2014a) empirically compared the financial condition of the famed chemical industry firms in the US by using several financial ratios. Moreover, Tsuji (2014b) performed an empirical comparison of the corporate financing behavior as to the some major US and Japanese firms in the electrical-related industries. Selahudin et al. (2014) researched the difference of earnings management, debt ratio, financial distress, and free cash flow of the corporations in Thailand and Malaysia. Further, Gazzola and Amelio (2014) studied the differences of the firm performance reporting selections between net profits and comprehensive incomes during the financial crises period. Furthermore, du Jardin (2015) proposed a new bankruptcy prediction methodology and this study also demonstrated that the suggested procedure in this study predicted better at a 3-year horizon than that achieved with common models. Regardless of the importance, in the existing literature, we cannot find the studies that investigated the financial state of the Japanese firms for the periods before and after the US Lehman shock.

Based on the situation documented above, this paper investigated the financial behavior of the Japanese firms focusing on, in particular, its difference in the periods before and after the Lehman shock in the US. Findings derived from our analyses using the Japanese time-series data are summarized as follows. First, (1) as to the financial condition in Japan, after the US Lehman shock, the current ratio, the debt ratio, the capital adequacy ratio of the Japanese firms 
clearly improved. Moreover, (2) the fixed assets ratio of the Japanese firms also clearly declined. Further, (3) with regard to the state of investments of the Japanese firms, the equity investments increased whilst the investments in bonds and real estates as well as the capital investments decreased. The rest of this paper is organized as follows. The second section documents our data and variables we analyze in this paper. The third section presents our overview of the evolution of the financial and investment behavior of the Japanese firms. The fourth section describes our further evidence we derived and the final section concludes the paper.

\section{DATA AND FINANCIAL RATIOS}

This section documents our data and variables. The variables we analyze in this study are constructed by using the Japanese firms' aggregate data, which are all supplied by the QUICK Corp. Our first variable is the current ratio, which is the ratio of current assets to current debt (percent). Second is the fixed assets ratio, which is the ratio of fixed assets to equity capital (percent). Third is the debt ratio, which is the ratio of total debts to equity capital (percent). Forth is the capital adequacy ratio, which is the ratio of equity capital to total assets (percent). Fifth is the ratio of investment equities to total investments (percent). Sixth is the ratio of investment bonds to total investments (percent). Seventh is the ratio of investment real estates to total investments (percent). Eighth is the ratio of capital investment to total assets (percent).

\section{OVERVIEW}

Table 1 displays the descriptive statistics for our above eight variables. This table shows the statistic values of mean, median, maximum, minimum, standard deviation, skewness, and kurtosis of the variables for our full sample period from January 2000 to September 2014. In addition, Figure 1 shows the monthly trends of the eight variables for the above full sample period. Panels A to D exhibit the state of financial condition of the Japanese firms. More concretely, first, Panel A of Figure 1 suggests that the current ratio of the Japanese firms continuously increases for the period. Panel B of Figure 1 displays that the fixed assets ratio of the Japanese firms continuously decreases for the period. Panel $\mathrm{C}$ of this figure indicates that the debt ratio of the Japanese firms continuously declines for the period. Panel D of this figure shows that the capital adequacy ratio of the Japanese firms continuously increases for the period.

Next, Panels E to $\mathrm{H}$ exhibit the state of investments of the Japanese firms. Specifically, first, Panel E of Figure 1 suggests that the ratio of investment equities to total investments of the Japanese firms continuously increases for our full sample period in general. Panel F of Figure 1 displays that the ratio of investment bonds to total investments of the Japanese firms continuously decreases for the period in general. Furthermore, Panel $\mathrm{G}$ and Panel $\mathrm{H}$ of this figure exhibit the time-series evolution of investment real estates to total investments and the capital investment to total assets of the Japanese firms for our full sample period. 
Table 1. Statistics of financial and investment ratios: For the full sample period from January 2000 to September 2014

\begin{tabular}{lllll}
\hline & Current ratio & Fixed assets ratio & Debt ratio & $\begin{array}{l}\text { Capital adequacy } \\
\text { ratio }\end{array}$ \\
\hline Mean & 123.4884 & 169.0514 & 209.7568 & 32.9727 \\
Median & 125.2143 & 156.7781 & 192.3670 & 34.1649 \\
Maximum & 139.3300 & 218.3701 & 316.9798 & 40.0980 \\
Minimum & 109.6447 & 135.0661 & 149.6053 & 23.9990 \\
Std. Dev. & 9.5150 & 25.2375 & 46.7614 & 4.6241 \\
Skewness & 0.0550 & 0.5294 & 0.6506 & -0.3669 \\
Kurtosis & 1.4212 & 1.7620 & 2.0752 & 1.7982 \\
\hline & Investment & Investment bonds & Investment real & Capital \\
& equities to total & to total & estates to total & investment to \\
& investments & investments & investments & total assets \\
\hline Mean & 56.6046 & 2.6197 & 0.3809 & 0.2788 \\
Median & 58.0120 & 2.6172 & 0.2953 & 0.2770 \\
Maximum & 66.1585 & 3.4421 & 1.0868 & 0.3642 \\
Minimum & 46.4257 & 2.1735 & 0.1630 & 0.2178 \\
Std. Dev. & 5.5390 & 0.3080 & 0.2311 & 0.0425 \\
Skewness & -0.1979 & 0.5255 & 1.6544 & 0.3488 \\
Kurtosis & 1.9739 & 2.4994 & 5.2662 & 1.9720 \\
\hline
\end{tabular}

Notes: This table presents the descriptive statistics of the eight variables used in this study. In this table, 'Std. Dev.' denotes the value of standard deviation. Samples are monthly and the sample period spans January 2000 to September 2014. The number of the monthly observations is 177.

\section{FURTHER EVIDENCE: BEFORE AND AFTER THE US LEHMAN SHOCK}

This section documents the further evidence of the financial behavior of the Japanese firms. We divide our full sample period into two sub-sample periods, which are 1) from January 2000 to August 2008 and 2) from September 2008 to September 2014. Table 2 displays the descriptive statistics as to our eight variables for the above two sub-periods, which are before and after the US Lehman shock (Panels A and B, respectively). Comparison of the results shown in Panel A and those in Panel B suggests the following evidence. First, the level of the current ratio of the Japanese firms increased after the Lehman shock; second, the level of the fixed assets ratio of the Japanese firms decreased after the Lehman shock; third, the level of the debt ratio of the Japanese firms declined after the Lehman shock; fourth, the level of the capital adequacy ratio of the Japanese firms increased after the Lehman shock.

Further, as to the state of investments of the Japanese firms, the investment equities to total investments of the Japanese firms increased after the Lehman shock; sixth, the investment bonds to total investments of the Japanese firms decreased after the Lehman shock; seventh, the investment real estates to total investments of the Japanese firms declined after the Lehman shock; eighth, the capital investment to total assets of the Japanese firms decreased after the Lehman shock. We consider that the decline of the fixed assets ratio of the Japanese firms after the US Lehman shock seems to be the result of the increase of the capital adequacy ratio and the decrease of the capital investment to total assets. 


\section{Panel A. Current ratio}

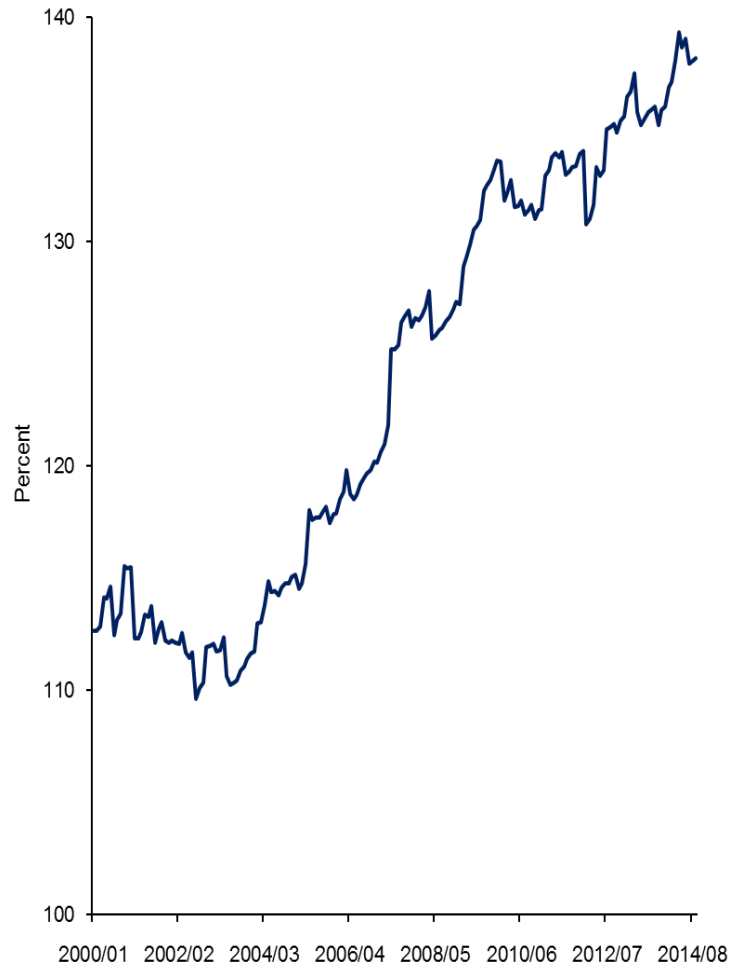

Panel C. Debt ratio

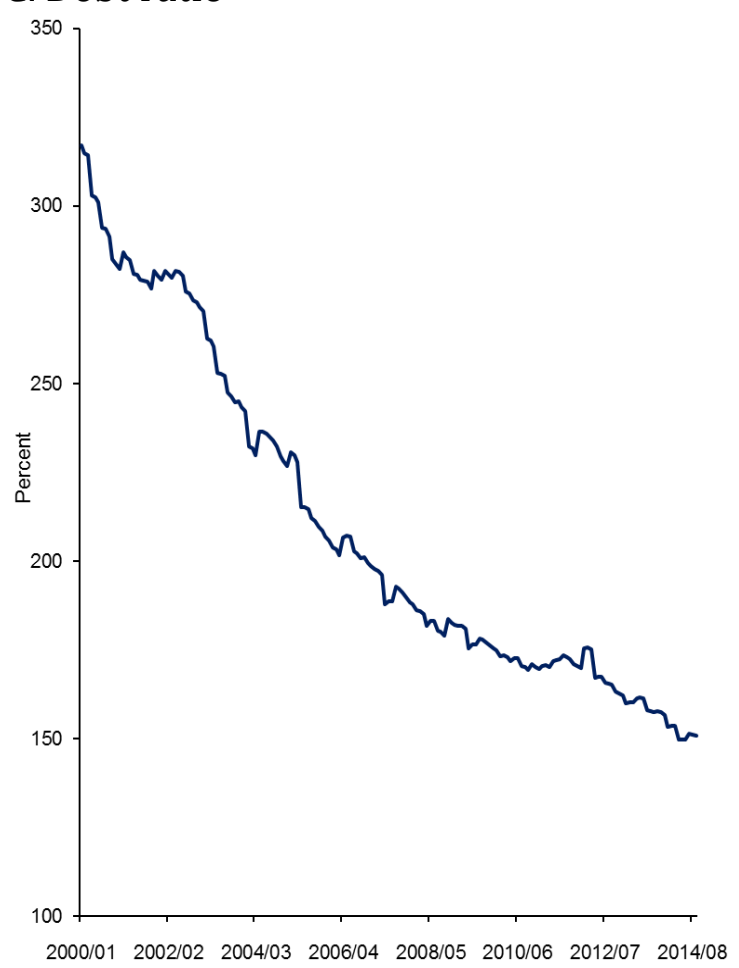

Panel B. Fixed assets ratio

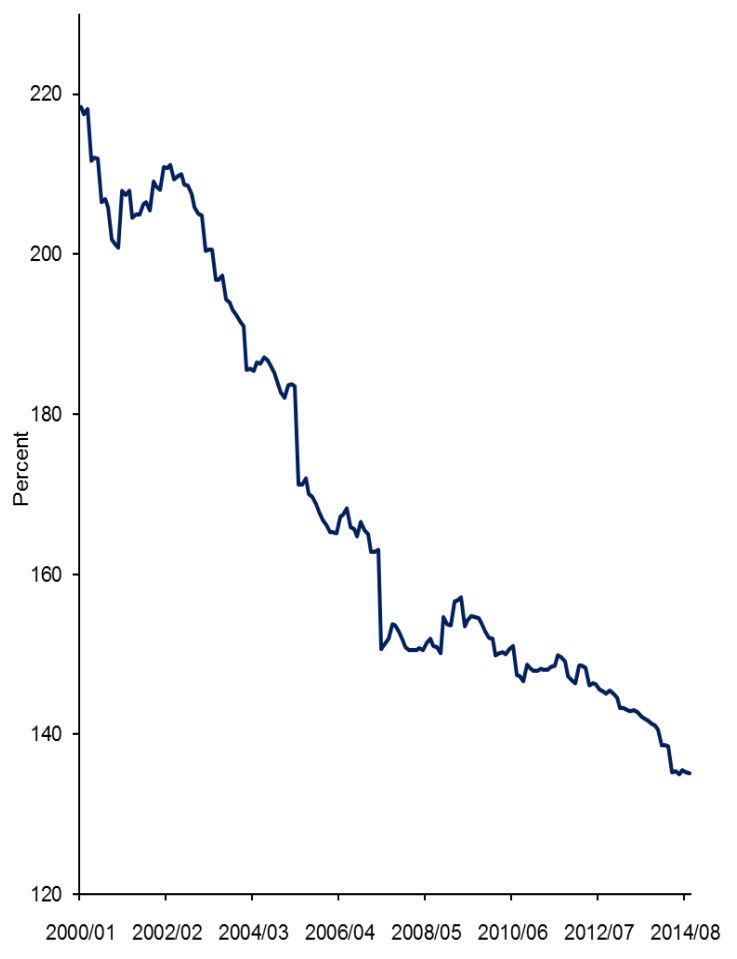

Panel D. Capital adequacy ratio

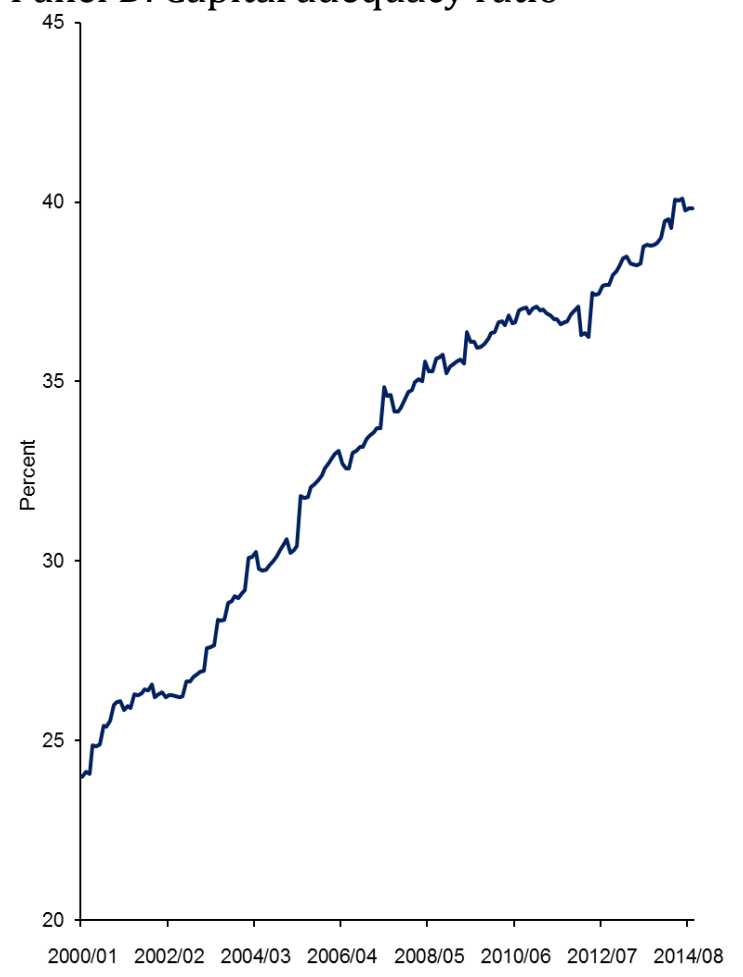


Panel E. Investment equities to total investments

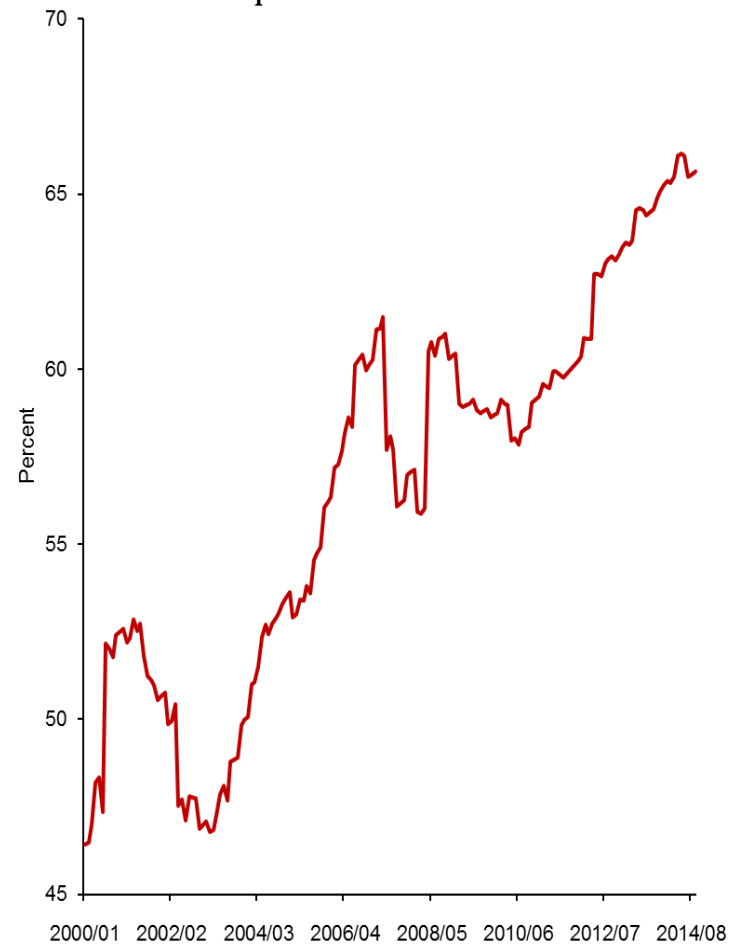

Panel G. Investment real estates to total investments

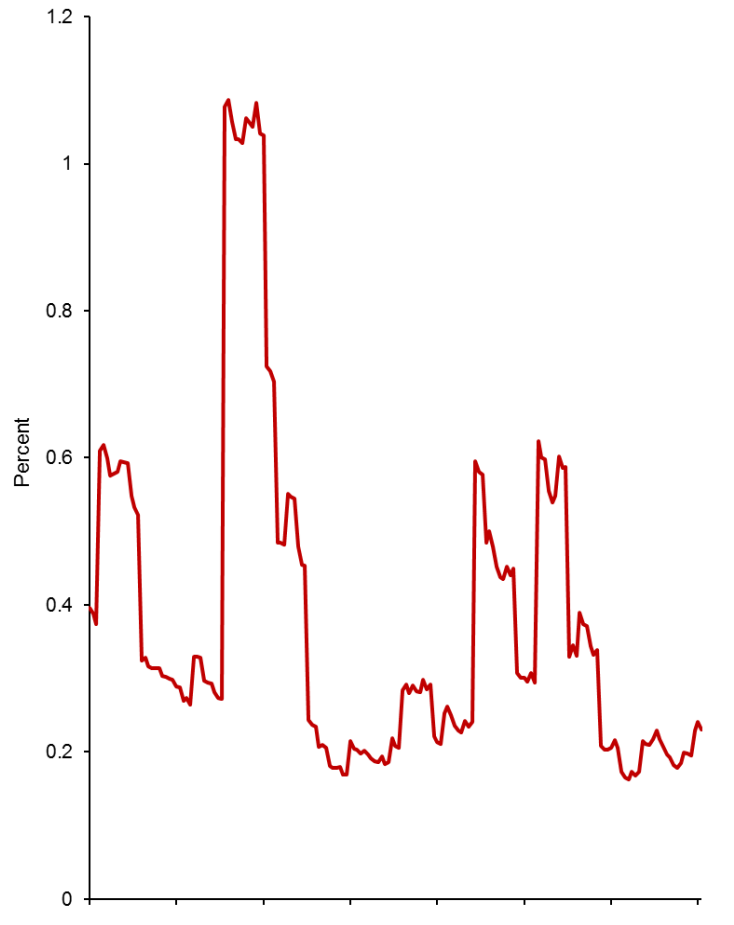

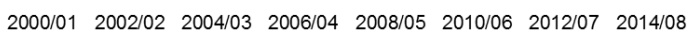

Panel F. Investment bonds to total investments

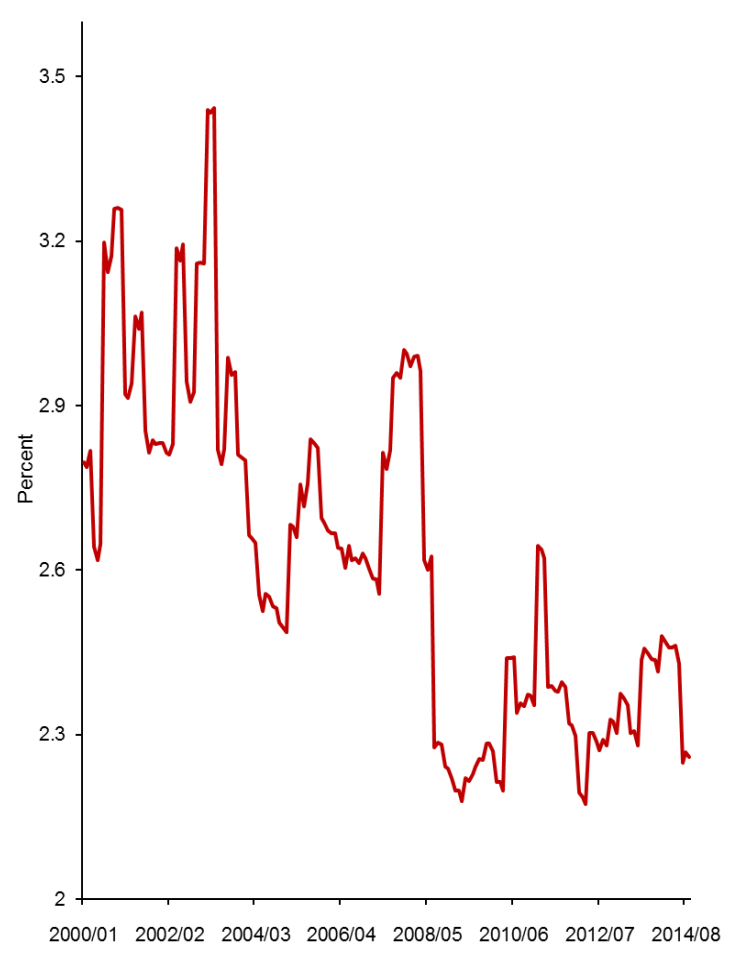

Panel H. Capital investment to total assets

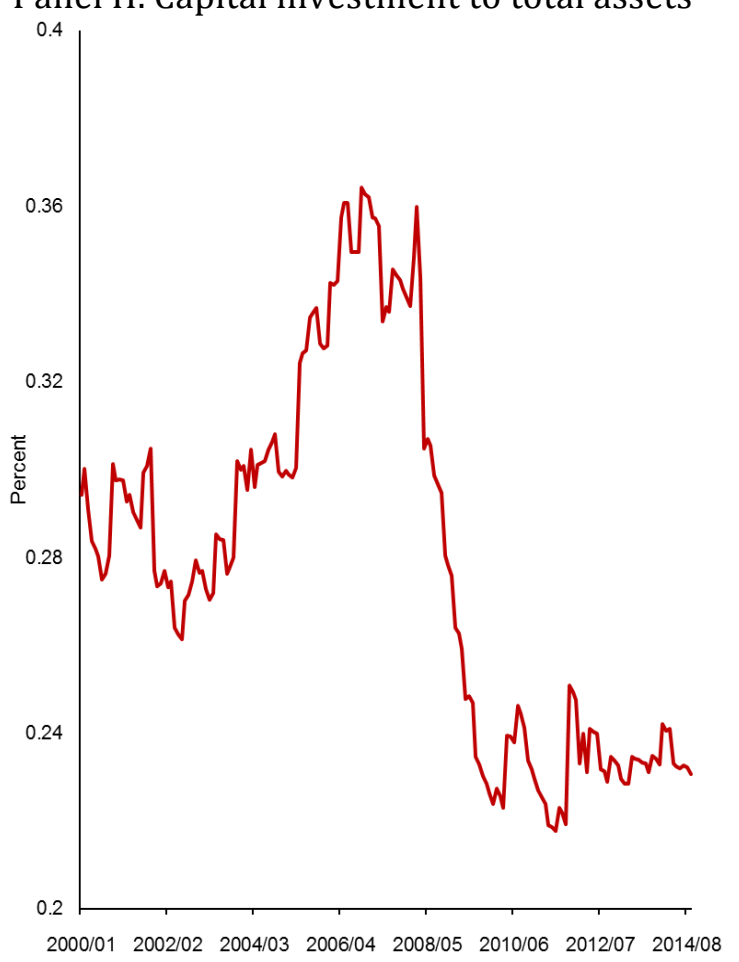

Figure 1. Evolution of the financial and investment ratios of the Japanese firms 
Table 2. Statistics of financial and investment ratios for the sub-sample periods: Before and after the US Lehman shock

\begin{tabular}{|c|c|c|c|c|}
\hline & Current ratio & Fixed assets ratio & Debt ratio & $\begin{array}{l}\text { Capital adequacy } \\
\text { ratio }\end{array}$ \\
\hline Mean & 116.4435 & 184.6087 & 239.1098 & 29.8896 \\
\hline Median & 114.6109 & 186.2526 & 234.3718 & 29.9464 \\
\hline Maximum & 127.7921 & 218.3701 & 316.9798 & 35.6577 \\
\hline Minimum & 109.6447 & 150.4891 & 180.1738 & 23.9990 \\
\hline Std. Dev. & 5.2275 & 21.7607 & 39.6044 & 3.4768 \\
\hline Skewness & 0.8527 & -0.2103 & 0.1471 & 0.0762 \\
\hline \multirow[t]{2}{*}{ Kurtosis } & 2.4847 & 1.6166 & 1.6836 & 1.6343 \\
\hline & $\begin{array}{l}\text { Investment } \\
\text { equities to total } \\
\text { investments }\end{array}$ & $\begin{array}{l}\text { Investment bonds } \\
\text { to total } \\
\text { investments }\end{array}$ & $\begin{array}{l}\text { Investment real } \\
\text { estates to total } \\
\text { investments }\end{array}$ & $\begin{array}{l}\text { Capital } \\
\text { investment to } \\
\text { total assets }\end{array}$ \\
\hline Mean & 53.2152 & 2.8198 & 0.4202 & 0.3079 \\
\hline Median & 52.7070 & 2.8116 & 0.2979 & 0.3003 \\
\hline Maximum & 61.4787 & 3.4421 & 1.0868 & 0.3642 \\
\hline Minimum & 46.4257 & 2.2761 & 0.1688 & 0.2614 \\
\hline Std. Dev. & 4.3950 & 0.2371 & 0.2697 & 0.0294 \\
\hline Skewness & 0.2505 & 0.5113 & 1.3921 & 0.4184 \\
\hline Kurtosis & 1.9959 & 3.0608 & 3.8183 & 1.9087 \\
\hline \multicolumn{5}{|c|}{ Panel B. From September 2008 to September 2014} \\
\hline & Current ratio & Fixed assets ratio & Debt ratio & $\begin{array}{l}\text { Capital adequacy } \\
\text { ratio }\end{array}$ \\
\hline Mean & 133.5250 & 146.8874 & 167.9388 & 37.3651 \\
\hline Median & 133.3163 & 147.9434 & 170.4152 & 36.9870 \\
\hline Maximum & 139.3300 & 157.0632 & 183.5728 & 40.0980 \\
\hline Minimum & 126.6367 & 135.0661 & 149.6053 & 35.2393 \\
\hline Std. Dev. & 2.8974 & 5.6452 & 9.1488 & 1.2977 \\
\hline Skewness & -0.1896 & -0.3942 & -0.4392 & 0.5420 \\
\hline \multirow[t]{2}{*}{ Kurtosis } & 2.8191 & 2.6249 & 2.2495 & 2.3261 \\
\hline & $\begin{array}{l}\text { Investment } \\
\text { equities to total } \\
\text { investments }\end{array}$ & $\begin{array}{l}\text { Investment bonds } \\
\text { to total } \\
\text { investments }\end{array}$ & $\begin{array}{l}\text { Investment real } \\
\text { estates to total } \\
\text { investments }\end{array}$ & $\begin{array}{l}\text { Capital } \\
\text { investment to } \\
\text { total assets }\end{array}$ \\
\hline Mean & 61.4335 & 2.3347 & 0.3251 & 0.2372 \\
\hline Median & 60.3500 & 2.3170 & 0.2498 & 0.2331 \\
\hline Maximum & 66.1585 & 2.6446 & 0.6225 & 0.2946 \\
\hline Minimum & 57.8341 & 2.1735 & 0.1630 & 0.2178 \\
\hline Std. Dev. & 2.6698 & 0.1059 & 0.1454 & 0.0145 \\
\hline Skewness & 0.4008 & 0.7891 & 0.7526 & 1.8230 \\
\hline Kurtosis & 1.6201 & 3.5852 & 2.1453 & 6.7999 \\
\hline
\end{tabular}

Notes: This table presents the descriptive statistics of the variables used in this study. In this table, 'Std. Dev.' denotes the value of standard deviation. Samples are monthly and the sample periods are from January 2000 to August 2008 in Panel A and from September 2008 to September 2014 in Panel B. The numbers of monthly observations are 104 in Panel $A$ and 73 in Panel B.

\section{CONCLUSIONS}

This paper researched the financial behavior of the Japanese firms by focusing on, in particular, its difference in the periods before and after the Lehman shock in the US, which occurred in September 2008. Interesting findings derived from our investigations using various Japanese 
corporations' financial and investment ratios, which were constructed by using the aggregate time-series data, are summarized as follows. First, (1) as to the financial condition in Japan, after the US Lehman shock, the current ratio, the debt ratio, the capital adequacy ratio of the Japanese firms clearly improved. Further, (2) the fixed assets ratio of the Japanese firms also clearly decreased after the Lehman shock. This is considered to be related to the decline of the capital investment and the increase of the capital adequacy ratio of the Japanese firms after the Lehman shock. Furthermore, (3) regarding the state of investments of the Japanese firms, the equity investments increased whilst the investments in bonds and real estates as well as the capital investments decreased after the Lehman shock.

It is considered that because of the continuous corporate efforts of the Japanese firms and the effects of the recent monetary easing executed by the Bank of Japan, the financial strength of the Japanese firms improved in the recent years. Further improvements and recovery of the financial strength and profitability of the Japanese firms in the future shall be also expected and the further rigorous quantitative analysis of the Japanese firms' financial behavior from various viewpoints is one of our future works.

\section{ACKNOWLEDGMENTS}

I am particularly grateful to the kind repeated invitation from the journal to write to this journal. I also appreciate the Japan society for the promotion of science, Zengin Foundation for Studies on Economics and Finance, and the Chuo university grant for special research for their generous financial assistance to this research. Finally, I deeply thank the Editors of this journal and Thomas Harvey for their kindness to this paper.

\section{References}

Ang, J. and Smedema, A. (2011). Financial flexibility: Do firms prepare for recession? Journal of Corporate Finance, 17, 774-787.

Chen, H.J. and Chen, S.J. (2012). Investment-cash flow sensitivity cannot be a good measure of financial constraints: Evidence from the time series, Journal of Financial Economics, 103, 393-410.

du Jardin, P. (2015). Bankruptcy prediction using terminal failure processes, European Journal of Operational Research, 242, 286-303.

Gazzola, P. and Amelio, S. (2014). The impact of comprehensive income on the financial ratios in a period of crises, Procedia Economics and Finance, 12, 174-183.

Selahudin, N.F., Zakaria, N.B., Sanusi, Z.M. and Budsaratragoon, P. (2014). Monitoring financial risk ratios and earnings management: Evidence from Malaysia and Thailand, Procedia - Social and Behavioral Sciences, 145, 5160.

Tsuji. C. (2014a). Exploring the financial ratios: The case study of the famed chemical industry firms in the US, Case Studies in Business and Management, 1, 11-21.

Tsuji. C. (2014b). An empirical comparison of the corporate financing behavior: The case study of the major US and Japanese firms in the electrical-related industries, International Finance and Banking, 1, 18-29. 